\title{
SUMBER ETIKA DALAM ISLAM
}

\author{
Oleh: \\ Hardiono * \\ Universitas Islam Sunan Kalijaga Yogyakarta \\ hardionouno11@gmail.com
}

\begin{abstract}
In this paper, we will discuss the ethical problems generated by Islam as was directly exemplified by the pioneer, enlightener and role model of all followers, namely the Prophet Muhammad SAW. The source of ethics in Islam (Islamic ethics) is the alQur'an and the Sunnah, both of which are always a measure of the merits of the actions committed by the Muslims. These two sources are a guide for human life to achieve happiness in this world and in the hereafter. The Prophet's behavior is the most factual interpretation of the Koran. In fact, in many narrations it is emphasized that the Prophet did not act / behave but because of the guidance of revelation, and the Prophet's morals were alQur'an. That is why in Islamic scholarship, including Islamic ethics, it does not give up its premises from the Qur'an and the Sunnah of the Prophet SAW. In Islam, the Quran and Sunnah will teach adherents from all sides, be it social, religious, cultural and so on. So in this paper we will discuss the sources of ethics in Islam (Islamic Ethics).

The method of this research is library research (library research), namely research that uses literature in the form of books, notes and reports on the results of previous research which will later become an analysis tool regarding ethics in Islam. The conclusion of this paper is that the source of ethics in Islam is al-Quran and as-Assunah, which will be the life guide for Muslims and non-Muslims to achieve true happiness, which the Prophet had exemplified directly from the above source.
\end{abstract}

Keywords: Ethics, happines, Al-Quran and as-Sunnah

\section{A. PENDAhuluan}

Etika pada umumnya
diidentikkan dengan moral
(moralitas). Meskipun sama terkait
dengan baik-buruk tindakan manusia,
etika dan moral memiliki perbedaan
pengertian. Secara singkat, jika moral

lebih cenderung pada pengertian "nilai baik dan huruk dari setiap perbuatan manusia, etika mempelajari tentang baik dan buruk". Jadi, bisa dikatakan, etika berfungsi sebagai teori dan perbuatan baik dan buruk (ethics atau 'ilm al-akhlaq) dan moral 
(akhlaq) adalah praktiknya. Akhlah merupakan bentuk praksis ajaran Islam dalam mengatur tindakan moral manusia. Akhlak juga sering didefinisikan sebagai ilmu tentang keutamaan-keutamaan dan cara mendapatkannya, sehingga dapat diterapkan dalam kehidupan seharihari dan ilmu tentang hal yang buruk dan bagaimana cara menjauhinya. (Taufik, 2016).

Sering pula yang dimaksud dengan etika adalah semua perbuatan yang lahir atas dorongan jiwa berupa perbuatan baik maupun buruk. Etika adalah salah satu cabang filsafat yang mempelajari tentang tingkah laku manusia, perkataan etika berasal dari bahasa Yunani yaitu Ethos yang berarti adat kebiasaan. Etika adalah sebuah pranata prilaku seseorang atau kelompok orang yang tersusun dari suatu sistem nilai atau norma yang diambil dari gejala-gejala alamiyah sekelompok masyarakat tersebut (Badroen, 2006).

Di dalam agama Islam pemakaian istilah etika disamakan dengan akhlak, adapun persamaannya terletak pada objeknya, yaitu keduanya sama-sama membahas baik buruknya tingkah laku manusia. Segi perbedaannya etika menentukan baik buruknya manusia dengan tolak ukur akal pikiran. Sedangkan akhlak dengan menentukannya dengan tolak ukur ajaran agama (al-Quran dan alSunnah) (Badroen, 2006).

Sumber etika dalam Islam (etika Islam) adalah al-Qur'an dan Sunnah yang mana kedua sumber tersebut selalu menjadi tolak ukur akan baik buruknya perbuatan yang dilakukan oleh kaum muslimin.
Kedua sumber ini juga selalu menjadi pedoman atau bisa disebut juga penuntun kehidupan manusia untuk meraih kebahagiaan di dunia maupun diakhirat.

Al-Qur'an adalah wahyu Allah yang disampaikan kepada umat Islam melalui Nabi Muhammad SAW. Perilaku Nabi dipandang sebagai penafsiran Al-Qur'an paling faktual. Bahkan di banyak riwayat ditegaskan bahwa Nabi tidak bertindak/berperilaku melainkan karena tuntunan wahyu, dan akhlak Rasulullah adalah Al-Qur'an. Itu sebabnya dalam keilmuan Islam, etika Islam tidak melepaskan dasar pemikirannya dari Al-Qur'an dan Sunah Nabi SAW. "Alif lam mim. Kitab (Al-Qur'an) ini tidak ada keraguan padanya, petunjuk bagi mereka yang bertaqwa" (QS. AlBaqarah : 1-2), (KEMENAG RI, 2006). "Sesunguhnya telah ada pada (diri) Rasulullah itu suri tauladan yang baik bagimu, (yaitu) bagi orang yang megharap (rahmat) Allah dan (kedatangan) hari kiamat, dan dia banyak menyebut nama Allah. (QS. Al-Ahzab : 21), "Aku tinggalkan untuk kamu dua perkara, tidaklah kamu akan sesat selama-lamanya, selama kamu masih berpegang kepada keduanya, yaitu kitabullah dan sunah rasul-Nya." (al-hadits).

Al-Qur'an merupakan kitab yang diturunkan Allah SWT kepada Nabi Muhammad SAW melalui perantara malaikat Jibril yang bertujuan terwujudnya insan kamil yang mempunyai posisi yang mulia di sisi Allah SWT serta memiliki nilai-nilai humanisme yang tinggi. Allah menurunkan wahyu melalui para Nabi-Nya, dan menjelaskan 
hukum-hukum kehidupan semua, itu semata-mata untuk kepentingan manusia sendiri, dan merupakan wujud kasih sayang kepada manusia, agar manusia memperoleh keselamatan dan kebahagiaan. (Asy'arie, 2002).

\section{B. METODE PENELITIAN}

Penelitian ini adalah
penelitian kepustakaan research) yaitu penelitian yang menggunakan literatur (kepustakaan) baik berupa buku, catatan maupun laporan hasil penelitian terdahulu (Iqbal Hasan, 2002, hlm.11.). Adapun sumber penelitian ini ada dua yakni sumber primer dan sumber skunder, sumber primer terkait dengan karya asli dari Majid Fakhry yakni: Etika Dalam Islam. Sedangkan sumber skundernya yang terkait dengan penelitian ini berupa buku, jurnal, artikel, majalah yang terkait dengan ini.

\section{PEMBAHASAN}

\section{Pengertian Etika}

Membicarakan pengertian etika tentu tak terlepas dari sejarah kemunculannya, yakni dimulai pada periode Islam klasik. Akan tetapi, berdasarkan manuskrip-manuskrip atau naskah-naskah kuno yang ditemukan dan diterjemahkan, karyakarya pemikiran Yunani klasik jauh lebih dulu ditulis. Hal tersebut diketahui berdasarkan konteks mata rantai sejarah ketika bangsa Arab menaklukkan sebuah wilayah, bahasa asli negara tersebut tidak dihilangkan atau diubah. (Alfan, 2011).

Kembali ke pengertian etika, menurut Burhanuddin Salam, istilah etika berasal dari kata latin, yakni "ethic", sedangkan dalam bahasa Greek, ethikos yaitu a body of moral principle or values. Ethic, arti sebenarnya ialah kebiasaan, habit. Jadi, dalam pengertian aslinya, apa yang disebutkan baik itu adalah yang sesuai dengan kebiasaan masyarakat (pada saat itu). Lambat laun pengertian etika itu berubah dan berkembang sesuai dengan perkembangan dan kebutuhan manusia. Perkembangan pengertian etika tidak lepas dari substansinya bahwa etika adalah suatu ilmu yang membicarakan masalah perbuatan atau tingkah laku manusia, mana yang dinilai baik dan mana yang buruk. Istilah lain dari etika, yaitu moral, susila, budi pekerti, akhlak. Etika merupakan ilmu bukan sebuah ajaran. (Salam, 2000). Etika dalam bahasa Arab disebut akhlaq, merupakan jamak dari kata khuluq yang berarti adat kebiasaan, perangai, tabiat, watak, adab, dan agama.

Masalah kemerosotan moral menjadi problem saat ini, meskipun demikian, tidak jelas faktor apa yang menjadi penyebabnya. Masalah moral adalah masalah yang muncul pada diri manusia, baik ideal maupun realita. Secara ideal ketika manusia diberikan roh oleh Allah untuk pertamakalinya dalam hidupnya, padanya disertakan rasio penimbang baik dan buruk. Oleh sebab itu masalah moral adalah masalah normatif. Di dalam hidupnya manusia dinilai atau akan melakukan sesuatu karena nilai. Nilai mana yang dituju tergantung pada tingkat pengertian akan nilai tersebut. Pengertian tersebut bahwa manusia memahami apa yang baik dan apa yang buruk 
serta ia dapat membedakan keduanya dan selanjutnya pada tahap pengamalannya.(Alfan, 2011).

Bagaimana dengan etika dalam Islam apakah ia memiliki kesamaan dengan etika pada umumnya? Adakah perbedaan etika Islam dengan etika pada umumnya? Majid Fakhri membagi aliran etika Islam menjadi empat kelompok. Pertama, moralitas skriptural, ini berarti sebuah tipe etika di mana keputusan-keputusan yang terkait dengan etika tersebut diambil dari alQur'an dan as-sunnah dengan memanfaatkan abstraksi-abstraksi dan analisis-analisis para filosof dan para teolog di bawah naungan metode-metode dan kategori-kategori diskursif yang berkembang pada abad 8 dan 9. Kelompok yang termasuk tipe etika ini sebagian para ahli tafsir dan para ahli hadits. Kedua, etika teologis ini berarti sebuah tipe etika dimana dalam mengambil keputusankeputusan etika, sepenuhnya mengambil dari al-Qur'an dan assunnah. Kelompok etika tipe ini ada pada kelompok aliran Mu'tazilah. Ketiga, etika filosofis. Tipe etika ini dimana dalam mengambil keputusankeputusan etika mendasarkan diri sepenuhnya pada tulisan Plato dan Aristoteles yang telah diinterpretasikan oleh para penulis Neo Platonik dan Galen yang telah digabung dengan doktrin-doktrin Stoa, Platonik, Phitagorian dan Aristotelian. Termasuk kelompok ini antara lain Ibnu Miskawaih dan penerusnya. Keempat, etika religius, merupakan tipe etika dimana keputusan etikanya berdasarkan alQur'an dan as-sunnah, konsepkonsep teologis, kategori-kategori filsafat, dan sedikit sufis. Unsur utama etika ini biasanya terkonsentrasi pada dunia dan manusia. Tipe pemikiran etika ini lebih kompleks dan berciri Islam. Bebrapa tokoh yang termasuk mempunyai tipe pemikiran etika ini, antara lain Hasan al Bashry, al Mawardi, al Ghazali, Fakhrudin ar Razi dll. (Haris, 2010).

Dalam Islam etika memiliki karakter yang khusus. Islam bukanlah agama takhayul yang mengajarkan penganutnya untuk mengisolasi diri dari masyarakat umum. Islam juga bukanlah agama yang mengatur masalah ritual saja. Namun, Islam mengajarkan penganutnya untuk beretika secara Islami yang mana telah diajarkan oleh agamanya sendiri (Islam) sehingga nilai-nilai etika ditegakkan untuk mengaturnya. Ajaran etika dalam Islam menyangkut seluruh sisi kehidupan manusia, yaitu beretika dengan sesama manusia, lingkungan, hewan dan lain sebgainya.

Kedudukan etika Islam dalam kehidupan manusia menempati tempat paling baik sebagai individu maupun sebagai anggota masyarakat. (Amin, 1983).Apabila etika seseorang itu baik maka ia akan sejahtera lahir dan batin namun jika etikanya buruk maka buruklah lahir batinnya.

Sumber-sumber etika Islam secara umum berhubungan dengan empat hal yaitu sebagai berikut:

a. Dilihat dari segi objek pembahasannya, etika berupaya membahas perbuatan yang dilakukan oleh manusia. 
b. Dari segi sumbernya, etika bersumber dari akal pikiran atau filsafat. Sebagai hasil pemikiran maka etika tidak bersifat mutlak, absolut dan tidak universal.

c. Dilihat dari segi fungsinya, etika berfungsi sebagai penilai, penentu dan penetap terhadap suatu perbuatan yang dilakukan oleh manusia yakni apakah perbuatan itu akan dinilai baik, buruk, mulia, terhormat, hina. Etika merupakan konsep atau pemikiran mengenai nilai-nilai untuk digunakan dalam menentukan posisi atau status perbuatan yang dilakukan manusia. Etika lebih mengacu kepada pengkajian sistem nilainilai yang ada.

d. Dilihat dari segi sifatnya, etika bersifat relatif yakni dapat berubah-ubah sesuai tuntunan zaman.

\section{Sumber Etika Dalam Islam (Etika Islam).}

Sumber etika Islam adalah alQur'an dan as-Sunnah. Sebagai sumber etika Islam, al-Qur'an dan asSunnah menjelaskan bagaimana cara berbuat baik. Kedua sumber etika Islam itu berfungsi sebagai pedoman umat untuk mengetahui bagaimana cara-cara berbuat baik sesuai dengan apa yang telah disampaikan ataupun dicontohkan langsung dari Rasulullah melalui tingkah laku beliau yang mengacu langsung dari al-Qur'an. Itulah yang menjadi landasan dan sumber dari ajaran Islam secara keseluruhan sebagai pola hidup dan menetapkan mana yang baik dan mana yang buruk. (Abdullah, 2006).

Al-Qur'an juga berfungsi sebagai pembenar dan penguji kitabkitab suci agama yang lain dan juga memuat konsep-konsep dan prinsipprinsip etik yang bertujuan untuk menghasilkan sikap-sikap yang benar bagi tindakan manusia, baik dalam tindakan politik, sosial, ekonomi dan terutama dalam perdangan. (Aziz, 2003). Di dalam ranah perdagangan saja kita lihat bahwa di situ seseorang dituntut untuk selalu ramah tamah ketika melakukan interaksi antar pembeli dan penjual, sebagaimana telah dicontohkan oleh Rasulullah untuk selalu jujur di dalam menimbang barang, mengisi harga jual dan mengambil keuntungan yang sesuai dengan harga telah ditentukan. Bukankah di sini telah mencerminkan sikap atau perilaku kita terhadap sesama yang mana telah dicontohkan langsung oleh Rasulullah untuk membentuk akhlak yang sesuai dengan perintah langsung dari alQur'an dan as-Sunnah. Maka di sini juga al-Qur'an pun turut andil menentukan hukum-hukum bagi mereka yang curang atau merugikan orang lain didalam melakukan perdagangan.

Fazlur Rahman menyatakan bahwa semangat dasar al-Qur'an adalah semangat moral, dengan landasan monotheisme untuk terwujudnya keadilan sosial. Hukum moral adalah abadi, ia adalah perintah Allah. Manusia tak dapat membuat atau memusnahkan hukum moral, ia harus menyerahkan diri kepadanya. Penyerahan ini dinamakan Islam dan implementasinya dalam kehidupan disebut ibadah atau pengabdian 
kepada Allah. Karena penekanan alQur'an terhadap hukum morallah hingga Allah di dalam al-Qur'an tampak bagi banyak orang terutama sebagai Tuhan keadilan. (Rahman, 2010).

Al-Qur'an adalah suatu ajaran yang bertujuan terutama untuk menghasilkan moral yang benar bagi tindakan manusia. Tindakan yang benar, apakah tindakan politik, keagamaan atau sosial, dipandang alQur'an sebagai ibadah atau pengabdian kepada Allah. Karena itu al-Qur'an mengutamakan semua penekanan-penekanan moral dan faktor-faktor psikologis yang melahirkan kerangka berpikir yang benar bagi tindakannya. Al Qur'an memperingatkan manusia terhadap kesombongan dan rasa cukup diri, yakni humanisme murni di satu pihak, dan putus asa serta hilang semangat hidup. (Rahman, 2010).

Hadits Rasulullah SAW merupakan pedoman yang kedua setelah al-Qur'an yang meliputi perkataan dan tingkah laku beliau. Hadits juga dipandang sebagai lampiran penjelasan dari al-Qur'an terutama dalam masalah-masalah yang tersurat pokok-pokoknya saja. Jadi telah jelas bahwa al-Qur'an dan as-Sunnah Rasul adalah pedoman hidup yang menjadi asas bagi setiap muslim, maka teranglah keduanya merupakan sumber etika Islam. Dasar etika Islam yang dijelaskan dalam alQur'an adalah sebagai berikut:

Di dalam al-Qur'an surah AlAhzab ayat 21 dikatakan "sesungguhnya telah ada pada diri Rasulullah itu suri teladan yang baik bagimu (yaitu) bagi orang yang mengharap (rahmat) Allah dan (kedatangan) hari kiamat dan dia banyak menyebut Allah. (QS. AlAhzab [33]: 21). Dan sesungguhnya kamu (Muhammad) benar-benar berbudi pekerti yang agung.

Etika dalam Islam merupakan misi kenabian yang paling utama setelah pengesaan Allah SWT (attauhid). Dalam hal ini Rasulullah pernah bersabda: "bahwasanya aku diutus untuk menyempurnakan akhlak yang baik". Dalam tataran khazanah keilmuan Islam, etika biasanya disebut dengan filsafat praktis. Ia menempati bagian penting di dalam diskursus pemikiran Islam klasik. Filsafat praktis itu sendiri berbicara tentang segala sesuatu bagaimana seharusnya yang berdasar kepada filsafat teoritis, yakni pembahasan tentang segala sesuatu sebagaimana adanya. (Taufik, 2016).

Tentang akhlak pribadi Rasulullah SAW dijelaskan pula oleh 'Aisyah r,a. Diriwayatkan oleh Imam Muslim. Dari 'Aisyah r.a. berkata, "sesungguhnya akhlak Rasulullah itu adalah al-Qur' an". (HR.Muslim). Hadits Rasulullah meliputi perkataan dan tingkah laku beliau, merupakan sumber akhlak yang kedua setelah alQur'an segala ucapan dan prilaku beliau senantiasa mendapat bimbingan dari Allah SWT. (Nasrul, 2015).

Majid Fakhry menegaskan di dalam bukunya Etika Dalam Islam, etika adalah menerangkan dan menginventarisasikan ayat-ayat alQur'an yang mencakup tiga masalah pokok yaitu: 1. Hakekat benar dan salah. 2. Keadilan dan kekuatan Tuhan. 3. Kebebasan dan 
tanggungjawab moral. Selain itu alQur'an juga menggunakan sekelompok istilah untuk menunjukkan konsep moral atau kebaikan religius seperti: al-khayr, albirr, al-qisth, al-iqsath, al-adl, alhaqq, al-ma'ruf dan at-taqwa. Sedangkan perbuatan dosa disebut sayyi'at. Perbuatan sayyi'at secara umum disebut itsm atau wizr yaitu dosa atau kejahatan, yang arti asalnya adalah beban. (Fakhry, 1996). Itulah istilah baik buruknya suatu perbuatan manusia di dalam al-Qur'an serta bagaimana penerapannya di dalam kehidupan sehari-hari.

Kita tahu bahwa etika merupakan bagian terpenting dari ajaran Islam, sebagaimana tampak dalam dua sumber utama ajaran Islam: al-Qur'an dan as-Sunnah. Itulah sebabnya, bahkan sebelum filsafat etika Islam berkembang, pembahasan tentang etika ini telah mendominasi pemikiran Islam awal. Di luar kedua sumber utama ajaran Islam itu, kita ketahui tasawuf (akhlaki) merupakan disiplin yang pertama kali berkembang, di samping teologi. Kita kenal di antara generasi kedua umat Islam, misalnya, Hasan Al- Bashri (w.728 M). Dia dikenal dengan penekanan pada asketisme (zuhud) dan kesalehan. Pada dasarnya kebijaksanaan sufistik seperti ini mengembangkan etika yang sebenarnya bersifat eskatologis (keakhiratan). Dengan kata lain, melihat dunia sebagai semata-mata batu loncatan untuk mencapai kebahagiaan di akhirat. Khususnya menurut al-Bashri, kesederhanaan duniawi dan bersifat penyayang merupakan dua akhlak terpenting. (Baghir, 2006).
Al-Qur'an dan juga AsSunnah sebagai sumber ke dua dalam Islam merupakan landasan epistemologis etika Islam, yang kemudian dikembangkan sedemikian rupa, sehingga mendorong seseorang melakukan perbuatan baik sebab, etika merupakan sebuah ramburambu di dalam bertindak yang akan membimbing dan mengingatkan seseorang untuk melaksanakan perbuatan yang bernilai demi kebermanfaatan dan kemaslahatan bersama. Hal tersebut sejalan dengan visi-misi al-Qur'an dan juga asSunnah sebagai pedoman umat Islam mencapai kebahagiaan dan keselamatan dunia-akhirat (Taufik, 2016). Sehingga sangat jelas bahwa, al-Qur'an juga as-Sunnah sebagai pelengkapnya merupakan sumber utama etika Islam, yang mengatur segala aspek dalam kehidupan manusia, termasuk aspek etis, moral, dan lainnya yang berkaitan dengan etika.

Etika Islam ditemukan dalam sumber yang terentang luas mulai dari Tafsir al-Quran hingga Kalam, dari komentar filosofis atas Aristoteles hingga teks mistik sufi. Para filsuf Islam juga turut andil dalam membahas masalah etika seperti Al-Farabi yang kita ketahui sebagai pembaca tekun karya Plato yaitu Republik dan Nicomachean Ethics Aristoteles. Al-Farabi dipengaruhi oleh pendahulu Yunaninya dalam pembahasanpembahasan tentang kebaikan manusia. Dari sini kita ketahui bersama bahwa etika Islam juga sudah dibahas dari beberapa abad oleh para filsu-filsuf Islam dimana 
mereka semua sangat peduli akan hal kebahagiaan manusia (Nasr, 2003).

Sekarang, kita beralih ke persoalan manusia. Kita telah melihat bahwa ketika memikirkan tentang kehidupan yang baik, kita menemukan fragmentasi antara klaim tentang penghormatan terhadap kebahagiaan orang lain. Kita dapat melihat hal tersebut dalam keduanya, namun tidak bisa meilhat bagaimana keduanya dapat disatukan. Persoalannya, filsafat sekuler tidak bisa memberikan jawaban yang memuaskan. Meski demikian, dalam perspektif religius kita bisa menemukan jawaban tersebut. Kebahagiaan personal dan perilaku patut secara moral memainkan peran dalam mengukuhkan hubungan dengan Tuhan. namun keduanya tidak diidentifikasi dengan tujuan tersebut dan tidak dianggap memiliki kontribusi independen terhadap penyatuan tersebut. Dalam apa yang oleh para teolog disebut sebagai "ekonomi ilahiah" kebahagiaan personal dan penghormatan pada orang lain adalah hal penting, namun keduanya memperoleh arti penting karena keduanya memiliki posisi dalam penyelamatan atau penebusan (Graham, 2014).

Jika kita lihat penjelasan dari sumber etika Islam yakni al-Quran dan as-Sunnah bahwa Tuhan pun turut andil dalam pemberi petunjuk dalam hal etika Islam, dengan begitu Tuhan sudah memberikan jalan bagi manusia supaya mengetahui dan memiliki moral yang baik dan meninggalkan perbuatan yang buruk, sehingga tercapailah apa yang dinamakan hakikat kebahagiaan tersebut.
3. Karakteristik Etika Islam

Hamzah Ya'qub menulis lima karakter etika Islam yang menurutnya dapat membedakannya dengan etika lain. Karakteristik etika Islam yang dimaksud, yaitu:

a. Etika Islam mengajarkan dan menuntun manusia kepada tingkah laku yang baik dan menjauhkan diri dari tingkah laku yang buruk.

b. Etika Islam menetapkan bahwa yang menjadi sumber moral, ukuran baik buruknya perbuatan, didasarkan kepada ajaran Allah Swt., yaitu ajaran yang berasal dari Al-Qur'an dan al-Hadis.

c. Etika Islam bersifat universal dan komprehensif, dapat diterima oleh seluruh umat manusia di segala waktu dan tempat.

d. Ajaran-ajarannya yang praktis dan tepat, cocok dengan fitrah (naluri) dan akal pikiran manusia (manusiawi), maka etika Islam dapat dijadikan pedoman oleh seluruh manusia.

e. Etika Islam mengatur dan mengarahkan fitrah manusia ke jenjang akhlak yang luhur dan meluruskan perbuatan manusia di bawah pancaran sinaran petunjuk Allah Swt. menuju keridaan-Nya (Haris, 2010).

Selain karakteristik etika Islam, sebagaimana yang dikemukakan di atas, Choirul Huda membuat aksioma etika Islam dengan 
berbagai indikatornya sebagai berikut:

Pertama, etika Islam bersifat unitas, yaitu berkaitan dengan konsep tauhid. Kedua, equilibrium. Konsep 'adl (keadilan) merupakan suasana keseimbangan di antara pelbagai aspek kehidupan manusia. Ketiga, kehendak bebas. Keempat, tanggung jawab. Kelima, ihsan yang merupakan suatu tindakan yang menguntungkan orang lain. Dari karakteristik dan aksioma etika Islam ini, dapatlah membantu kita dalam memahami bagaimana konsep etika Islam.

Seorang Muslim memiliki keterkaitan terhadap hukum Allah, karena Islam melalui sumber AlQur'an dan Hadis mengatur secara global semua hal dan perbuatan yang berkaitan dengan perbuatan manusia. Allah telah menjadikan Islam agama yang memiliki ajaran secara sempurna, berskala internasional, manusiawi dan autentik. Kepatuhan terhadap ikatan hukum syara' tersebut dapat mendatangkan rahmatan lil'alamin, kedamaian, ketentraman dan kebahagiaan dunia dan di akhirat (Haris, 2010).

Sebaliknya, sifat yang
menentang dapat
mendatangkan laknat, siksaan dan azab Allah, seperti kerusakan (individu dan sosial), kegelisahan bathin dan berbagai kerugian lainnya. Untuk mencari kebahagiaan dan tujuan-tujuan baik lainnya, harus menggunakan jalan baik dan benar, yaitu jalan yang hanya ditempuh manusia dengan mengikuti aturanaturan dan ketentuan-ketentuan yang digariskan oleh Allah, aturan-aturan tersebut sesuai dengan akal manusia, dan tidak berlawanan dengannya, karena akal turut menentukan baik dan buruknya suatu perbuatan. Menurut Al-Ghazali, "Perbuatan yang disebut baik apabila sesuai dengan akal dan syara', perbuatan yang tidak baik apabila bertentangan dengan akal dan syara'." Menurut ajaran Islam yang menentukan baik dan buruknya perbuatan pertama kali adalah nash, yaitu Al-Qur'an yang berisi aturan dan ketentuan Allah, kemudian hadis Nabi yang berfungsi sebagai penjelas, akal yang mendapat bimbingan Allah dan niat baik seseorang dalam melakukannya (Abdullah, 2006).

\section{Kesimpulan}

Etika Islam lahir dari persentuhan dengan banyak keilmuan lain dari luar Islam, seperti Yunani. Sumber utama etika Islam adalah alQur'an dan As-Sunnah yang merupakan sumber utama dalam Islam. Di dalamnya terentang berbagai aturan moral yang sangat luhur dan penjelas atas hal-hal yang tidak dipahami manusia. Semangat moral yang terdapat dalam al-Qur'an merupakan satu landasan penting dalam kehidupan sehari-hari. Sehingga tidak berlebihan jika dikatakan bahwa, al-Qur'an merupakan kitab moral yang terlengkap. Selain al-Qur'an juga terdapat As-Sunnah yang menjadi pelengkap al-Qur'an, di mana ajaran Rasulullah SAW terdapat di dalamnya. Kedua sumber inilah yang menjadi dasar dalam etika Islam.

Selain sumber, etika Islam juga mempunyai karakteristik yang khas, yaitu: (1)Etika Islam 
mengajarkan dan menuntun manusia kepada tingkah laku yang baik dan menjauhkan diri dari tingkah laku yang buruk. (2) Etika Islam menetapkan bahwa, yang menjadi sumber moral, ukuran baik dan buruknya perbuatan seseorang didasarkan pada al-Qur'an dan AsSunnah. (3) Etika Islam bersifat universal dan komprehensif, dapat diterima dan dijadikan pedoman oleh seluruh umat manusia, kapanpun dan di manapun mereka berada. (4) Etika Islam mengatur dan mengarahkan fitrah manusia ke jenjang akhlak yang luhur dan mulia, serta meluruskan perbuatan manusia sebagai upaya memanusiakan manusia dan sering kita sebut yaitu humanisme. Untuk itu sumber etika dalam Islam juga membentuk manusia insan kamil.

\section{Daftar Kepustakaan}

Azis, Abdul, 2013. Etika Bisnis Perspektif Islam: Implementasi Etika Islami Untuk Dunia Usaha, Bandung: Al-Fabet.

Amin, Ahmad, 1983. Etika: Ilmu Akhlak, Jakarta: Bulan Bintang.

Taufik, Muhammad, 2016. "Etika Dalam Perspektif Filasafat Islam “ dalam Etika: Perspektip, Teori dan, Praktik, (ed) Zuhri Yogyakarta: FA Press.

Badroen, Faisal, 2006. Etika Bisnis Dalam Islam, Jakarta : Kencana Perdana Media Group, Cet. Ke- 1

Asy'arie, Musa, 2002. Filsafat Islam: Sunnah Dalam Berpikir. Yogyakarta: LESFI.

Alfan, Muhammad, 2011. Filsafat Etika Islam, Bandung: Pustaka Setia.

Salam, Burhanuddin, 2000. Etika Individual, Jakarta: Renika Cipta.

Suseno,Frans, Magnis, 1987. Etika Dasar, Yogyakarta: Kanisius.

Haris, Abd, 2010. Etik Hamka konstruksi Etika Berbasis Rasional Religius, Yogyakarta: LkiS.

Abdullah, M. Yatimin, 2006. Pengantar Studi Etika, Yogyakarta: PT Raja Grafindo Persada.

Rahman, Fazlur, 2010. Islam, Bandung: Pustaka.

Nasrul, 2015. Akhlak Tasawuf, Yogyakarta: Aswaja Presinndo.

Kementrian Agama RI, 2016. ArRahim al-Qur'an dan Terjemah. Bandung: CV Mikraj Khazanah Ilmu.

Fakhry, Majid, 1996. Etika Dalam Islam, Yogyakarta: Pustaka Pelajar. 
Baghir, Haidar, 2006. Buku Saku Filsafat Islam, Bandung: PT. Mizan Pustaka.

Hasan, M. Iqbal. 2002, Pokok-pokok materi Metodologi Penelitian dan Aplikasinya, Jakarta: Ghalia Indonesia.

Nasr, Hossein, Sayyed dan Leaman, Oliver. 2003, Ensiklopedia Tematis Filsafat Islam (Buku kedua), Bandung: PT Mizan Pustaka.

Graham, Gordon, 2014. Teori-teori Etika, Bandung: Nusa Media

Haris, Abd, 2010. Etika Hamka Kontruksi Berbasis RasionalReligius, Yogyakarta: LkiS 